\title{
ANALISIS LIKUIDITAS TERHADAP HARGA SAHAM PERUSAHAAN TELEKOMUNIKASI DALAM KONDISI FINANCIAL DISTRESS: BURSA EFEK INDONESIA 2009-2013
}

\author{
Gunarsih dan Daryanto Hesti Wibowo \\ Sekolah Tinggi Ilmu Administrasi Mandala Indonesia \\ gunarsih0511@yahoo.co.id,wibowodar@gmail.com
}

\begin{abstract}
The research analyzes the influence of liquidity consisting of CR and DER ratio of stock prices. This study uses financial ratio analysis and multiple regression analysis. The results of multiple regression analysis with the test statistic $F$ variables $C R$ and DER showed together had effect on stock prices. Similarly, the partial variable CR had effect on stock prices, because $t_{\text {count }} \geq$ $t_{\text {table }}$, and variable DER had no effect on stock prices, because $t_{\text {count }} \leq t_{\text {table }}$.
\end{abstract}

Keywords: Financial Distress, Analysis of Financial Ratios, Current Ratio (CR), Total Debt to Total Equity (DER), Stock Price.

\begin{abstract}
Abstrak. Penelitian ini menganalisis pengaruh likuiditas dengan rasio CR dan DER terhadap harga saham. Penelitian ini menggunakan analisis rasio keuangan dan analisis regresi berganda. Hasil penelitian dari analisis regresi berganda dengan uji statistik F variabel CR dan DER menunjukkan secara bersama-sama berpengaruh terhadap harga saham. Demikian juga secara parsial variabel CR berpengaruh terhadap harga saham, karena $t_{\text {hitung }} \geq t_{\text {tabel }}$ dan DER tidak berpengaruh terhadap harga saham, karena $t_{\text {hitung }} \leq t_{\text {tabel. }}$.
\end{abstract}

Kata kunci: Financial Distress, Analisis Rasio Keuangan, Current Ratio (CR), Total Debt to Total Equity (DER), Harga Saham.

Perusahaan telekomunikasi yang GoPublic merupakan perusahaan yang tercatat sahamnya di Bursa Efek Indonesia (BEI). Perdagangan sekuritas pada sektor industri telekomunikasi saat ini menjadi salah satu bisnis yang menguntungkan, sehingga menyebabkan banyak investor yang tertarik untuk terlibat dalam bisnis di bidang telekomunikasi (Fahmi, 2012)

Terjadinya pergerakan harga saham secara fluktuatif dari masing-masing perusahaan menunjukkan harga saham yang terus bergerak seiring dengan permintaan pembelian saham dari investor.

Tingkat kemampuan suatu perusahaan untuk dapat bersaing sangat ditentukan oleh kinerja perusahaan itu sendiri. Perusahaan yang tidak mampu bersaing untuk mempertahankan kinerjanya lambat laun akan tergusur dari lingkungan industrinya dan akan mengalami kebangkrutan.

Perusahaan yang mengalami kebangkrutan biasanya diawali oleh gejala financial distress. Menurut Platt dan Platt (2002) Financial distress dapat didefinisikan sebagai tahap penurunan kondisi keuangan yang terjadi sebelum terjadinya kebangkrutan atau likuidasi. Selain itu, terdeteksinya kondisi financial distress dapat dilihat dari kondisi perusahaan yang mengalami laba bersih (net income) negatif selama beberapa tahun. Menurut Hofer (1980) dan Whitaker (1999). Sementara Luciana (2006) mendefinisikan kondisi financial distress sebagai suatu kondisi bahwa perusahaan mengalami delisted akibat laba bersih dan nilai buku ekuitas negatif berturutturut serta perusahaan tersebut telah di-merger.

Damodaran (2001) menyatakan, faktor penyebab financial distress dari dalam perusahaan lebih bersifat mikro, faktor-faktor dari dalam perusahaan tersebut adalah: (1) Kesulitan arus kas. Perusahaan tidak cukup untuk menutupi beban-beban usaha yang timbul atas aktivitas operasi perusahaan. Kesulitan arus kas juga disebabkan adanya kesalahan manajemen ketika mengelola aliran kas perusahaan untuk pembayaran aktivitas perusahaan yang memperburuk kondisi 
keuangan perusahaan; (2) Besarnya jumlah utang. Kebijakan pengambilan utang perusahaan untuk menutupi biaya yang timbul akibat operasi perusahaan akan menimbulkan kewajiban bagi perusahaan untuk mengembalikan utang di masa depan. Ketika tagihan jatuh tempo dan perusahaan tidak mampu mempunyai cukup dana untuk membayar tagihan-tagihan kreditur adalah mengadakan penyitaan harta perusahaan untuk menutupi kekurangan pembayaran tagihan tersebut; (3) Kerugian dalam kegiatan operasional perusahaan selama beberapa tahun. Salah satu cara yang dapat dilakukan untuk memprediksi kondisi financial distress perusahaan adalah dengan menganalisis laporan keuangan perusahaan.

Standar Akuntansi Keuangan (IAI, 2007) menyatakan tujuan umum laporan keuangan adalah menyediakan informasi yang menyangkut posisi keuangan suatu perusahaan yang bermanfaat bagi sejumlah besar pengguna laporan dalam pengambilan keputusan ekonomi serta menunjukkan pertanggungjawaban (stewardship) manajemen atas penggunaan sumber daya yang dipercayakan kepada mereka.

Salah satu penyebab kesulitan keuangan menurut Brigham dan Daves (Anggarini, 2010) adalah serangkaian kesalahan, pengambilan keputusan yang tidak tepat, dan kelemahankelemahan yang saling berhubungan yang dapat menyumbang secara langsung maupun tidak langsung kepada manajemen serta tidak adanya atau kurangnya upaya mengawasi kondisi keuangan sehingga penggunaan uang tidak sesuai dengan keperluan.

Salah satu dampak financial distress adalah dapat membawa perusahaan mengalami kesulitan dalam membayarkan kewajiban yang ditanggung. Menurut Anggarini (2010), perusahaan yang mengalami financial distress (kesulitan keuangan) akan menghadapi kondisi: (a) Tidak mampu memenuhi jadwal atau kegagalan pembayaran kembali hutang yang sudah jatuh tempo kepada kreditor; (b) Perusahaan dalam kondisi tidak solvable (insolvency).

Harga saham akan meningkat jika kinerja perusahaan baik dan tidak mengalami financial distress. Dengan harga saham yang meningkat tersebut berarti akan meningkatkan kemakmuran pemegang saham. Harga saham juga dapat dipengaruhi oleh kemampuan manajemen perusahaan untuk beroperasi secara menguntungkan di tengah-tengah lingkungan usaha yang semakin kompetitif.

Dengan terdeteksinya kondisi financial distress lebih awal pada perusahaan, sangat memungkinkan bagi perusahaan untuk melakukan langkah-langkah antisipasi agar perusahaan dapat menyelesaikan masalah financial distress dengan segera sehingga tidak terjadi kebangkrutan.

Dari latar belakang di atas maka dapat diidentifikasi masalah-masalah sebagai berikut: (1) Terjadi penurunan likuiditas pada perusahaan yang mengalami financial distress; (2) Perusahaan dalam kondisi financial distress mengalami kerugian; (3) Harga saham perusahaan dalam kondisi financial distress menurun.

Penelitian ini dilakukan pada perusahaan telekomunikasi yang terdapat di Bursa Efek Indonesia periode 2009-2013 yang sedang mengalami kondisi financial distress, yaitu perusahaan yang minimal mengalami kerugian selama dua tahun berturut-turut.

Tujuan dalam penelitian ini adalah untuk mengetahui pengaruh likuiditas terhadap harga saham perusahaan telekomunikasi yang mengalami financial distress.

Penelitian ini diharapkan bermanfaat bagi pembaca sebagai bahan informasi untuk mengetahui perkembangan harga saham disaat perusahaan sedang mengalami kondisi financial distress, dan sebagai informasi untuk perusahaan lain dalam mendeteksi serta mencegah kondisi financial distress sejak dini.

\section{METODE PENELITIAN}

Metode yang digunakan dalam penelitian ini adalah metode kuantitatif dengan pendekatan dalam bentuk deskriptif sekaligus kausalitas. Penelitian kuantitatif deskriptif adalah penelitian yang bersifat mengumpulkan, menyederhanakan, menyajikan, dan mengelola data kuantitatif secara deskriptif agar dapat memperoleh suatu kesimpulan. Sedangkan penelitian kausalitas adalah penelitian yang 
bertujuan untuk mengetahui pengaruh suatu variabel independen terhadap variabel dependen.

Teknik pengumpulan data melalui: (1) Dokumentasi, metode mengumpulkan data dari laporan-laporan yang telah diolah oleh pihak lain sehingga peneliti dapat memperoleh informasi yang dibutuhkan; (2) Riset kepustakaan, mengumpulkan dan mempelajari bahan-bahan yang dapat mendukung penelitian dari berbagai sumber literatur sehingga memperkuat landasan teori untuk dilakukannya pengujian atau pembahasan terhadap obyek penelitian.

Untuk mengolah data mentah menjadi angka pembanding antar rasio dalam bentuk persen yang mudah untuk dipahami. Sedangkan Munawir (2004) mendefinisikan analisis rasio keuangan adalah suatu metode analisis untuk mengetahui hubungan pos-pos tertentu dalam neraca atau laporan laba rugi secara individu atau kombinasi dari kedua laporan tersebut. Selain itu, menurut Keown (2002), tujuan dari analisis rasio adalah untuk membantu manajer keuangan memahami apa yang perlu dilakukan oleh perusahaan, berdasarkan informasi yang tersedia dalam laporan keuangan.

Uji likuiditas dengan menggunakan rumus:

$$
\begin{aligned}
\text { Current Ratio }= & \frac{\text { Aktiva Lancar }}{\text { Utang Lancar }} \\
\text { Total Debt to Equity Ratio } & \\
& =\frac{\text { Total Utang }}{\text { Modal Pemegang Saham }}
\end{aligned}
$$

Teknik pengolahan data dengan program Statistical Product and Service Solutions (SPSS versi 22).

\section{Statistik Deskriptif}

Statistik deskriptif berhubungan dengan pengumpulan dan peringkasan data, serta penyajian hasil ringkasan tersebut. Data statistik yang biasa diperoleh dalam penelitian ini umumnya masih acak dan tidak terorganisasi dengan baik. Data tersebut harus diringkas dengan teratur, baik dalam bentuk tabel atau persentasi grafis, sebagai dasar untuk berbagai pengambilan keputusan. Alat analisis yang digunakan adalah dengan rata-rata (mean) dan standar deviasi dengan menggunakan SPSS versi 22.

\section{Pengujian Asumsi Klasik}

Pengujian ini dilakukan untuk memperoleh parameter yang valid dan handal. Pengujian asumsi klasik terdiri dari uji normalitas, uji multikolinearitas, uji autokorelasi dan uji heteroskedastisitas.

\section{Analisis Regresi Linier Berganda}

Alat uji yang digunakan untuk analisis penelitian ini adalah Regresi Linier Berganda (multiple regression) untuk melihat pengaruh $\mathrm{CR}\left(\mathrm{X}_{1}\right)$ dan DER $\left(\mathrm{X}_{2}\right)$ terhadap harga saham (Y). Model regresi linier berganda adalah sebagai berikut:

$\begin{array}{lll}\mathrm{Y}=\mathrm{a}+\mathrm{b}_{1} \mathrm{X}_{1} & +\mathrm{b}_{2} \mathrm{X}_{2}+\mathrm{e} \\ \text { Keterangan : } & & \\ \mathrm{Y} & = & \text { harga saham } \\ \mathrm{a} & = & \text { Konstanta } \\ \mathrm{b}_{1}-\mathrm{b}_{2} & = & \text { Koefisien regresi } \\ \mathrm{X}_{1} & = & \text { CR } \\ \mathrm{X}_{2} & = & \text { DER } \\ \mathrm{e} & = & \text { Error term }\end{array}$

\section{Uji Koefisien Determinan $\left(\mathbf{R}^{2}\right)$}

Untuk dapat mengetahui seberapa besar variasi pada harga saham di Bursa Efek Indonesia dapat diterangkan oleh kontribusi variabel-variabel bebas, yaitu CR dan DER.

Nilai koefisien determinasi berkisar antara $0<\mathrm{R}^{2}>1$. Nilai $\mathrm{R}^{2}$ yang mendekati 1 menunjukkan kontribusi yang besar dari variabel bebas terhadap perubahan yang terjadi pada variabel terikat. Sebaliknya nilai $R^{2}$ yang 0 menunjukkan kontribusi yang kecil dari variabel bebas terhadap perubahan yang terjadi pada variabel terikat.

\section{Teknik Pengujian Hipotesis}

$\mathrm{Ho}_{1}$ :CR tidak berpengaruh terhadap terhadap harga saham.

$\mathrm{Ha}_{1}$ :CR berpengaruh signifikan terhadap harga saham.

$\mathrm{Ho}_{2}$ :DER tidak berpengaruh terhadap harga saham.

$\mathrm{Ha}_{2}$ :DER berpengaruh signifikan terhadap harga saham. 
Tabel 1. Hasil Perhitungan Rasio Keuangan dan Rata-rata Harga Saham

\begin{tabular}{|c|c|c|c|c|}
\hline \multirow[b]{2}{*}{ Nama Perusahaan } & \multicolumn{2}{|c|}{$\begin{array}{l}\text { Rasio Keuangan } \\
\text { (Dalam \%) }\end{array}$} & \multirow{2}{*}{$\begin{array}{c}\text { Rata-rata } \\
\text { Harga Saham } \\
\text { (Rp) } \\
\text { (Y) } \\
\end{array}$} & \multirow[b]{2}{*}{$\begin{array}{l}\text { Profitabilitas } \\
\text { (Rp) }\end{array}$} \\
\hline & $\begin{array}{l}C R \\
\left(\mathbf{X}_{1}\right)\end{array}$ & $\begin{array}{r}D E R \\
\left(\mathbf{X}_{2}\right)\end{array}$ & & \\
\hline \multicolumn{5}{|l|}{2009} \\
\hline \multicolumn{5}{|l|}{ PT Telekomunikasi Indonesia } \\
\hline (Persero) Tbk & 60,58 & 122,17 & 8.095 & 11.332 .140 .000 .000 \\
\hline PT Smartfren Telecom Tbk & 42,28 & 500,22 & 50 & $(724.396 .366 .372)$ \\
\hline PT Indosat Tbk & 54,63 & 207,02 & 5.205 & 1.498.245.000.000 \\
\hline PT XL Axiata Tbk & 33,40 & 211,02 & 2.693 & 1.709 .468 .000 .000 \\
\hline $\begin{array}{c}\text { PT Bakrie Telecom Tbk } \\
\mathbf{2 0 1 0}\end{array}$ & & 98.442.112.191 \\
\hline \multicolumn{5}{|l|}{ PT Telekomunikasi Indonesia } \\
\hline (Persero) Tbk & 90,29 & 97,57 & 7.105 & 11.536 .999 .000 .000 \\
\hline PT Smartfren Telecom Tbk & 21,52 & $(3852,51)$ & 50 & $(1.401 .813 .486 .084)$ \\
\hline PT Indosat Tbk & 51,55 & 193,72 & 4.966 & 724.019 .000 .000 \\
\hline PT XL Axiata Tbk & 48,82 & 132,61 & 5.241 & 2.891 .261 .000 .000 \\
\hline \multirow{2}{*}{\multicolumn{5}{|c|}{2011}} \\
\hline & & & & \\
\hline \multicolumn{5}{|l|}{ PT Telekomunikasi Indonesia } \\
\hline (Persero) Tbk & 95,80 & 68,99 & 7.145 & 15.481 .000 .000 .000 \\
\hline PT Smartfren Telecom Tbk & 25,63 & 276,16 & 71 & $(2.400 .247 .590 .614)$ \\
\hline PT Indosat Tbk & 55,04 & 177,27 & 5.432 & 932.503 .000 .000 \\
\hline PT XL Axiata Tbk & 38,80 & 127,64 & 4.816 & 2.830 .101 .000 .000 \\
\hline PT Bakrie Telecom Tbk & 31,65 & 179,55 & 250 & (782.699.191.424) \\
\hline \multicolumn{5}{|l|}{2012} \\
\hline \multicolumn{5}{|l|}{ PT Telekomunikasi Indonesia } \\
\hline (Persero) Tbk & 116,03 & 66,27 & 10.359 & 18.388 .000 .000 .000 \\
\hline PT Smartfren Telecom Tbk & 28,14 & 187,69 & 96 & $(1.563 .090 .528 .610)$ \\
\hline PT Indosat Tbk & 75,43 & 184,73 & 5.941 & 875.860 .000 .000 \\
\hline PT XL Axiata Tbk & 41,86 & 130,68 & 5.264 & 2.743.915.000.000 \\
\hline PT Bakrie Telecom Tbk & 26,75 & 452,65 & 50 & $(3.138 .935 .665 .528)$ \\
\hline \multicolumn{5}{|l|}{2013} \\
\hline PT Telekomunikasi Indonesia & & & & \\
\hline (Persero) Tbk & 116,30 & 65,26 & 2.316 & 20.402 .000 .000 .000 \\
\hline PT Smartfren Telecom Tbk & 36,36 & 420,22 & 64 & $(2.534 .463 .228 .719)$ \\
\hline PT Indosat Tbk & 53,12 & 230,07 & 3.885 & $(2.644 .087 .000)$ \\
\hline PT XL Axiata Tbk & 73,68 & 163,24 & 4.767 & 1.055 .965 .000 .000 \\
\hline PT Bakrie Telecom Tbk & 8,94 & $(1.006,04)$ & 50 & $(2.645 .565 .576 .416)$ \\
\hline
\end{tabular}

Sumber: Hasil olah data 2014

$\mathrm{Ho}_{3}$ :CR dan DER tidak berpengaruh terhadap harga saham.

$\mathrm{Ha}_{3}: \mathrm{CR}$ dan DER berpengaruh signifikan terhadap harga saham.

Ho ditolak, jika $t_{\text {hitung }}>t_{\text {tabel, }}$ artinya, variabel independen mempunyai pengaruh yang signifikan terhadap variabel dependen. Ho diterima, jika $t_{\text {hitung }} \leq \mathrm{t}_{\text {tabel }}$ artinya, variabel independen tidak mempunyai pengaruh yang signifikan terhadap variabel dependen.

\section{HASIL PENELITIAN}

(lihat tabel 1)
Dari output di atas dapat dilihat bahwa variabel current ratio dengan jumlah data $(\mathrm{N})$ sebanyak 25 mempunyai rata-rata presentase sebesar 55,6880\% dengan standar deviasinya sebesar 29,12685\%. Variabel DER dengan jumlah data $(\mathrm{N})$ sebanyak 25 mempunyai ratarata presentase sebesar $-15,8788 \%$ dengan standar deviasinya sebesar $842,07484 \%$.

Variabel harga saham dengan jumlah data (N) sebanyak 25 mempunyai rata-rata harga saham sebesar Rp3374,68 dengan standar deviasinya sebesar Rp3130,678. 


\section{Statistik Deskriptif}

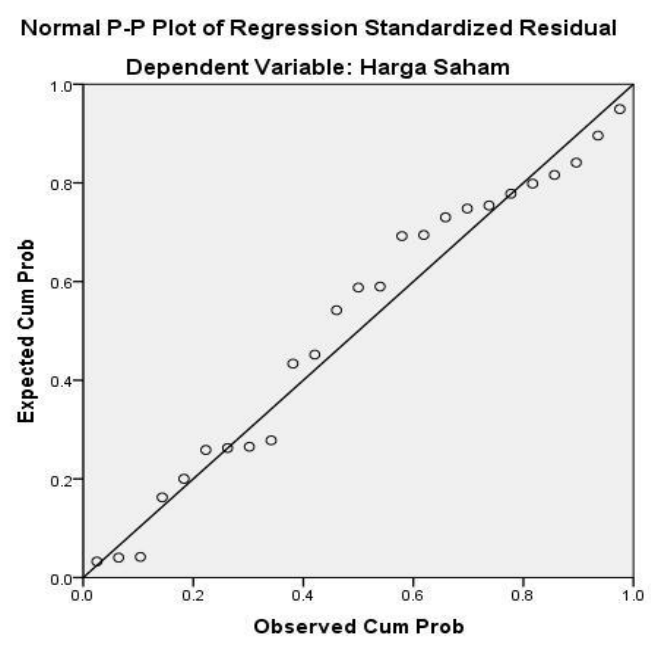

Gambar 1

Tabel 2

\section{Coefficients $^{\mathrm{a}}$}

\begin{tabular}{|ll|r|l|}
\hline \multirow{2}{*}{ Model } & & \multicolumn{2}{|c|}{ Collinearity Statistics } \\
\cline { 3 - 4 } & & Tolerance & \multicolumn{1}{c|}{ VIF } \\
\hline 1 & CR & .935 & 1.069 \\
& DER & .935 & 1.069 \\
\hline
\end{tabular}

a. Dependent Variable: Harga Saham

\section{Pengujian Asumsi Klasik Uji Normalitas}

(lihat gambar 1)

Dari gambar di atas bisa dikatakan tersebar di sekeliling garis lurus (tidak terpencar jauh dari garis lurus) serta penyebaran mengikuti arah garis diagonal. Dengan demikian, hal ini mengindikasikan bahwa tidak terdapat masalah normalitas antarvariabel independen.

\section{Uji Multikolinearitas}

(lihat tabel 2)

Berdasarkan Tabel di atas diketahui bahwa keseluruhan variabel independen mempunyai nilai VIF kurang dari batas maksimal 10 atau nilai Tolerance yang lebih besar dari 0,10 . Dengan demikian $\mathrm{H}_{\mathrm{o}}$ diterima, artinya seluruh variabel independen yang digunakan pada model persamaan regresi ini terbebas dari multikolinearitas sehingga hasil regresinya dapat dipercaya.

\section{Uji Autokorelasi}

(lihat tabel 3)

Berdasarkan tabel 3 diketahui bahwa nilai DW yang dihasilkan dari model regresi adalah 2,419 yang berada di antara $D_{U}=1,567$ dan (4$\mathrm{dU})=2,433$ sehingga dapat disimpulkan tidak ada autokorelasi pada model regresi ini. 


\section{Tabel 3}

Model Summary

\begin{tabular}{|l|c|}
\hline Model & $\begin{array}{l}\text { Durbin- } \\
\text { Watson }\end{array}$ \\
\hline 1 & $2.419^{\mathrm{a}}$ \\
\hline
\end{tabular}

a. Predictors:

(Constant), DER, CR

b. Dependent Variable: Harga Saham

Charts

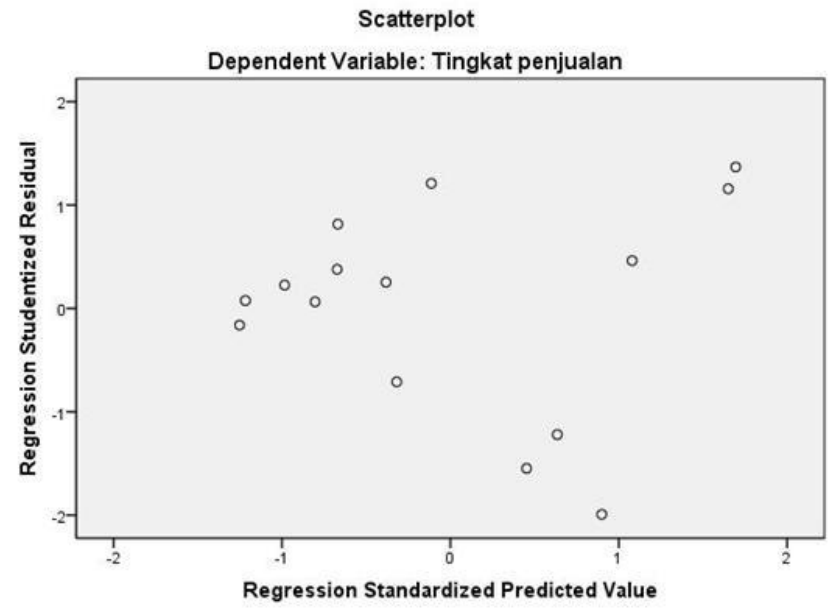

Gambar 2

Tabel 4

Coefficients $^{a}$

\begin{tabular}{|c|c|c|c|c|c|c|}
\hline \multirow{2}{*}{\multicolumn{2}{|c|}{ Model }} & \multicolumn{2}{|c|}{ Unstandardized Coefficients } & \multirow{2}{*}{$\begin{array}{c}\text { Standardized } \\
\text { Coefficients } \\
\text { Beta }\end{array}$} & \multirow[b]{2}{*}{$\mathrm{t}$} & \multirow[b]{2}{*}{ Sig. } \\
\hline & & B & Std. Error & & & \\
\hline \multirow[t]{3}{*}{1} & (Constant) & 63.536 & 1210.940 & & .052 & .959 \\
\hline & Current Ratio & 59.521 & 19.444 & .554 & 3.061 & .006 \\
\hline & $\begin{array}{l}\text { Total Debt to Total Equity } \\
\text { Ratio }\end{array}$ & .220 & .673 & .059 & .326 & .747 \\
\hline
\end{tabular}

a. Dependent Variable: Harga Saham

\section{Uji Heteroskedastisitas}

(lihat Gambar 2)

Dalam gambar di atas tampak bahwa pola titik data residual menyebar dengan tidak memiliki pola tertentu, sehingga dapat dikatakan bahwa modal regresi memenuhi asumsi atau terbebas dari gejala heteroskedastisitas.

\section{Analisis Regresi Linier Berganda}

Persamaan regresi dari hasil tabel di atas adalah:

(lihat tabel 4)

$\mathrm{Y}=\mathrm{a}+\mathrm{b}_{1} \mathrm{X}_{1}+\mathrm{b}_{2} \mathrm{X}_{2}+\mathrm{e}$
$Y=63,536+59,521 X_{1}+0,220 X_{2}+e$

Interpretasi:

Nilai konstanta $\mathrm{a}=63,536$ memberikan arti bahwa jika variabel bebas diabaikan atau dengan kata lain jika tidak ada variasi pada CR dan DER, maka harga saham akan bernilai Rp63,536.

Nilai koefisien $b_{1}=59,521$, berarti bahwa setiap ada kenaikan satu satuan pada CR, dengan asumsi variabel independen lainnya tetap, maka harga saham akan mengalami kenaikan sebesar Rp59,521 dan bergerak ke arah yang sama. 


\section{Tabel 5}

Model Summary ${ }^{b}$

\begin{tabular}{|c|c|c|c|c|c|c|c|c|c|c|}
\hline \multirow[b]{2}{*}{ Model } & \multirow[b]{2}{*}{$R$} & \multirow[b]{2}{*}{ R Square } & \multirow[b]{2}{*}{$\begin{array}{l}\text { Adjusted R } \\
\text { Square }\end{array}$} & \multirow[b]{2}{*}{$\begin{array}{l}\text { Std. Error of } \\
\text { the Estimate }\end{array}$} & \multicolumn{5}{|c|}{ Change Statistics } & \multirow[b]{2}{*}{$\begin{array}{l}\text { Durbin- } \\
\text { Watson }\end{array}$} \\
\hline & & & & & $\begin{array}{l}\text { R Square } \\
\text { Change }\end{array}$ & FChange & df1 & df2 & $\begin{array}{l}\text { Sig. F } \\
\text { Change }\end{array}$ & \\
\hline 1 & $.572^{\mathrm{d}}$ & .327 & .266 & 2682.875 & .327 & 5.340 & 2 & 22 & .013 & 2.419 \\
\hline
\end{tabular}

a. Predictors: (Constant), Total Debsto Total Equity Ratio, Current Ratio

\section{b. Dependent Variable: Harga Saham}

Tabel 6

Coefficients

\begin{tabular}{|ll|r|r|r|r|r|}
\hline \multirow{2}{*}{ Model } & \multicolumn{2}{|c|}{ Unstandardized Coefficients } & $\begin{array}{c}\text { Standardized } \\
\text { Coefficients }\end{array}$ & & \\
\cline { 3 - 5 } & \multicolumn{1}{|c|}{$\mathrm{B}$} & \multicolumn{1}{c|}{ Std. Error } & \multicolumn{1}{c|}{ Beta } & \multicolumn{1}{c|}{ Sig. } \\
\hline 1 & (Constant) & 63.536 & 1210.940 & & .052 & .959 \\
& Current Ratio & 59.521 & 19.444 & .554 & 3.061 & .006 \\
& $\begin{array}{l}\text { Total Debt to Total Equity } \\
\text { Ratio }\end{array}$ & .220 & .673 & .059 & .326 & .747 \\
\hline
\end{tabular}

a. Dependent Variable: Harga Saham

Nilai koefisien $b_{2}=0,220$, berarti bahwa setiap ada kenaikan satu satuan pada DER, dengan asumsi variabel independen lainnya tetap, maka harga saham akan mengalami kenaikan sebesar Rp0,220 dan bergerak ke arah yang sama.

\section{Uji Koefisien Determinan $\left(\mathbf{R}^{\mathbf{2}}\right)$}

\section{(lihat tabel 5)}

Dari tabel di atas, dapat dilihat bahwa koefisien korelasi (R), yaitu sebesar 0,572. Nilai tersebut menunjukkan bahwa korelasi atau hubungan antara variabel independen (CR dan DER) dinyatakan memiliki hubungan yang tinggi dengan nilai korelasi di atas 0,399.

Sedangkan nilai koefisien determinasi (Adjusted $R$ Square) menghasilkan angka sebesar 0,266 yang berarti bahwa harga saham (Y) dapat dijelaskan oleh variabel-variabel independen $\mathrm{CR}\left(\mathrm{X}_{1}\right)$ dan DER $\left(\mathrm{X}_{2}\right)$ sebesar 0,266 atau sebesar $26,6 \%$. Sedangkan sisanya sebesar $73,4 \%$ dijelaskan oleh faktor-faktor lain yang tidak terdapat dalam penelitian ini.

\section{Uji Hipotesis}

\section{Uji t (Pengujian Hipotesis I dan II)}

(lihat tabel 6)
Berdasarkan hasil regresi pada tabel diatas diketahui bahwa variabel independen CR menghasilkan nilai $t_{\text {hitung }}$ sebesar 3,061 yang lebih besar dari $t_{\text {tabel }} 2,073$ dan mempunyai nilai signifikansi ( $p$-value) di bawah 0,05 yaitu sebesar 0,006. Sehingga dapat dikatakan bahwa $\mathrm{Ho}_{1}$ ditolak yang berarti variabel CR berpengaruh terhadap harga saham. Dan variabel independen DER menghasilkan nilai $\mathrm{t}_{\text {hitung }}$ sebesar 0,326 yang lebih kecil dari $\mathrm{t}_{\text {tabel }}$ 2,073 dan mempunyai nilai signifikansi ( $p$ value) di atas 0,05 yaitu sebesar 0,747. Sehingga dapat dikatakan bahwa $\mathrm{Ho}_{2}$ diterima yang berarti variabel DER tidak berpengaruh terhadap harga saham.

Uji F (Pengujian Hipotesis III) (lihat tabel 7)

Berdasarkan hasil uji $\mathrm{F}$ pada tabel di atas diketahui bahwa secara simultan (bersamasama) variabel independen yang terdiri dari CR dan DER menghasilkan nilai $F_{\text {hitung }}$ sebesar 5,340 yang lebih besar dari $F_{\text {tabel }} 3,443$ dan mempunyai nilai signifikansi (p-value) di bawah 0,05 yaitu sebesar 0,013 . Sehingga dapat 


\section{Tabel 7}

ANOVA $^{\mathrm{a}}$

\begin{tabular}{|ll|c|r|r|l|l|}
\hline Model & & \multicolumn{1}{c|}{$\begin{array}{c}\text { Sum of } \\
\text { Squares }\end{array}$} & df & Mean Square & F & Sig. \\
\hline 1 & Regression & 76875438.87 & 2 & 38437719.43 & 5.340 & $.013^{\mathrm{b}}$ \\
& Residual & 158352026.6 & 22 & 7197819.390 & & \\
& Total & 235227465.4 & 24 & & & \\
\hline
\end{tabular}

a. Dependent Variable: Harga Saham

b. Predictors: (Constant), Total Debt to Total Equity Ratio, Current Ratio

dikatakan bahwa Ho3 ditolak yang berarti variabel independen $\mathrm{CR}$ dan DER secara simultan berpengaruh terhadap harga saham.

\section{PEMBAHASAN}

PT Telekomunikasi Indonesia (Persero) berdasarkan hasil CR menunjukkan kondisi keuangan perusahaan selalu mengalami peningkatan dari 2009-2013 begitu pula DER menurun dari tahun ke tahun dan dilihat dari perkembangan rata-rata harga saham cenderung naik dari tahun ke tahun. Dilihat dari profitabilitas yang diperoleh setiap tahun mengalami peningkatan maka dapat dikatakan bahwa PT Telekomunikasi Indonesia (Persero) Tbk tidak mengalami kondisi financial distress.

PT Smartfren Telecom dapat diketahui bahwa berdasarkan hasil CR menunjukkan kondisi keuangan perusahaan mulai mengalami penurunan di awal tahun 2009 karena utang lancar lebih besar dari harta lancar yang dimiliki perusahaan begitu pula DER di awal tahun 2009 angkanya tinggi. Jika dilihat dari perkembangan rata-rata harga saham ternyata penurunan kondisi keuangan sudah memengaruhi harga saham perusahaan di awal tahun 2009. Dilihat dari profitabilitas dari tahun 2009 sudah mengalami kerugian maka dapat dikatakan bahwa PT Smartfren Telecom Tbk sudah mengalami kondisi financial distress di awal tahun 2009. Emrinaldi (2007) menyatakan kondisi yang paling mudah dilihat dari perusahaan yang mengalami financial distress adalah pelanggaran komitmen pembayaran utang diiringi dengan penghilangan pembayaran deviden terhadap investor.

PT Indosat Tbk, dapat diketahui bahwa dilihat dari hasil $\mathrm{CR}$ perusahaan mengalami penurunan kondisi keuangan di tahun 2013 dan mengalami peningkatan hasil DER di tahun 2013. Penurunan kondisi keuangan perusahaan mulai memengaruhi harga saham ditahun 2013, yaitu rata-rata harga saham $\mathrm{Rp} 3.885$,- dan dilihat dari profitabilitas di tahun 2013 mengalami kerugian maka dapat dikatakan bahwa PT Indosat Tbk mengalami kondisi financial distress di tahun 2013.

PT. XL Axiata Tbk, dapat diketahui bahwa dilihat dari hasil CR perusahaan mengalami peningkatan kondisi keuangan di awal tahun 2010 dan hasil DER mengalami penurunan di tahun 2011 kemudian naik kembali ditahun 2012 serta rata-rata harga saham di tahun 20092013 cenderung naik dan stabil. Dilihat dari profitabilitas setiap tahun mengalami penurunan namun tidak sampai menyebabkan kerugian, maka dapat dikatakan bahwa PT XL Axiata Tbk mulai mengalami kondisi financial distress di tahun 2011.

PT Bakrie Telecom Tbk, dapat diketahui bahwa dilihat dari hasil CR perusahaan mengalami penurunan kondisi keuangan dari tahun ke tahun dan hasil DER mengalami kenaikan yang cukup drastis, serta rata-rata harga saham mengalami penurunan di 20122013. Dilihat dari profitabilitas di tahun 20112013 mengalami kerugian, maka dapat dikatakan bahwa PT Bakrie Telecom Tbk mulai mengalami kondisi financial distress di tahun 2011.

\section{Simpulan}

Analisis likuiditas berpengaruh terhadap harga saham. Hal ini terbukti bahwa harga saham (Y) dapat dijelaskan oleh variabelvariabel independen CR (X1) dan DER (X2) 
sebesar 0,266 atau sebesar 26,6\%. Sedangkan sisanya sebesar 73,4\% dijelaskan oleh faktorfaktor lain yang tidak dilakukan dalam penelitian ini.

Langkah-langkah perusahaan untuk mengatasi keadaan financial distress di antaranya dengan menjual sebagian besar asset dari perusahaan sehingga didapat uang tunai untuk meningkatkan kembali likuiditas perusahaan dan melanjutkan kembali kinerja operasional perusahaan, melakukan merger tanpa proses likuidasi, mengurangi beberapa biaya yang kurang signifikan serta dengan menerbitkan sekuritas baru.

Penelitian ini menggunakan harga saham lima hari sebelum dan lima hari setelah laporan keuangan audit diterbitkan. Sebaiknya penelitian selanjutnya menggunakan rentang waktu yang lebih panjang. Waktu yang lebih panjang akan menghasilkan pengujian yang lebih akurat.

\section{DAFTAR PUSTAKA}

Anggarini, Tivani Vota. 2010. "Pengaruh Karakteristik Komite Audit Terhadap Financial Distress (Studi Empiris pada Perusahaan yang Terdaftar di Bursa Efek Indonesia)" Skripsi S-1, Program Studi Akuntansi Universitas Diponegoro.

Brigham, Eugene F and Philip R. Daves. 2003. Intemediete Financial Management. Eight Edition. Thomson. South-Western. P.837859.

Damodaran, Aswath. 2001. Corporate Finance: Theory and Practice. 2nd ed. USA: John Wiley\&Sons, Inc
Emrinaldi, Nur DP. 2007. "Analisis Pengaruh Praktek Tata Kelola Perusahaan (Corporate Governance) terhadap Kesulitan Keuangan Perusahaan" Financial Distress: Suatu Kajian Empiris. Jurnal Bisnis dan Akuntansi. Vol 9, No.1 p 84-108

Fahmi, Irham. 2011. Analisis Laporan Keuangan. Bandung: Alfabeta.

Hofer, C.W.1980. "Turnaround Strategies". Journal of Business Strategy 1:19-31

Ikatan Akuntan Indonesia. 2007. Standar Akuntansi Keuangan (SAK). Jakarta: Salemba Empat Patria.

Keown, J. Arthur et al. 2002. Dasar-Dasar Manajemen Keuangan. Jakarta: Salemba Empat.

Munawir. 2002. Analisa Laporan Keuangan. Yogyakarta: Liberty.

Platt, H., dan M. B. Platt. 2002. "Predicting Financial Distress." Journal of Financial Service Professionals. 56: 12-15

Spica, Luciana. 2006. "Prediksi Financial Distress Perusahaan Go Public dengan Menggunakan Analisis Multinomial Logit." Jurnal Ekonomi dan Bisnis. Maret Vol. XII No. 1 ISSN 0854-9087

Whitaker, R.B. 1999. "The Early Stages of Financial Distress". Journal of Economics and Finance. 23:123-133. 